\title{
Shift from widespread symbiont infection of host tissues to specific colonization of gills in juvenile deep-sea mussels
}

\author{
Cecilia Wentrup ${ }^{1}$, Annelie Wendeberg ${ }^{2}$, Julie Y Huang ${ }^{3}$, Christian Borowski ${ }^{1}$ and \\ Nicole Dubilier ${ }^{1}$ \\ ${ }^{1}$ Max Planck Institute for Marine Microbiology, Symbiosis Group, Bremen, Germany; ${ }^{2}$ Department of \\ Environmental Microbiology, UFZ, Helmholtz Centre for Environmental Research, Leipzig, Germany and \\ ${ }^{3}$ Department of Microbiology and Immunology, Stanford University, Stanford, CA, USA
}

\begin{abstract}
The deep-sea mussel Bathymodiolus harbors chemosynthetic bacteria in its gills that provide it with nutrition. Symbiont colonization is assumed to occur in early life stages by uptake from the environment, but little is known about this process. In this study, we used fluorescence in situ hybridization to examine symbiont distribution and the specificity of the infection process in juvenile $B$. azoricus and $B$. puteoserpentis $(4-21 \mathrm{~mm})$. In the smallest juveniles, we observed symbionts, but no other bacteria, in a wide range of epithelial tissues. This suggests that despite the widespread distribution of symbionts in many different juvenile organs, the infection process is highly specific and limited to the symbiotic bacteria. Juveniles $\geqslant 9 \mathrm{~mm}$ only had symbionts in their gills, indicating an ontogenetic shift in symbiont colonization from indiscriminate infection of almost all epithelia in early life stages to spatially restricted colonization of gills in later developmental stages.
\end{abstract}

The ISME Journal (2013) 7, 1244-1247; doi:10.1038/ismej.2013.5; published online 7 February 2013

Subject Category: microbe-microbe and microbe-host interactions

Keywords: Bathymodiolus; Mid-Atlantic Ridge; symbiont transmission; hydrothermal vents

\section{Introduction}

Associations with chemosynthetic bacteria have evolved independently in at least four lineages of marine bivalves (Dubilier et al., 2008). In all these associations, the symbionts are generally restricted to the gills in adult bivalves (Taylor and Glover, 2010), except hosts that transfer their symbionts directly to their offspring and harbor symbionts in their gonads (Endow and Ohta, 1990; Cary and Giovannoni, 1993). In adult Bathymodiolus mussels, symbionts have only been observed in the gills (Distel et al., 1994; Duperron, 2010). These mussels occur worldwide at hydrothermal vents and cold seeps and harbor their intracellular sulfurand methane-oxidizing symbionts in gill cells called bacteriocytes. Bathymodiolus is assumed to acquire

Correspondence: C Wentrup or N Dubilier, Max Planck Institute for Marine Microbiology, Symbiosis Group, Celsiusstr. 1, Bremen 28359, Germany.

E-mail: cwentrup@mpi-bremen.de or ndubilie@mpi-bremen.de or A Wendeberg, Department of Environmental Microbiology, UFZ, Helmholtz Centre for Environmental Research, Permoserstraße 15, Leipzig 04318, Germany.

E-mail: annelie.wendeberg@ufz.de

Received 9 July 2012; revised 15 November 2012; accepted 18 December 2012; published online 7 February 2013 its symbionts from the environment, but the developmental stage at which this occurs is not known (Won et al., 2003; Duperron et al., 2007). Post-larval Bathymodiolus azoricus and B. heckerae as small as $0.12 \mathrm{~mm}$ appear to already harbor symbionts in their gills based on transmission electron microscopy (TEM) observations of bacteria morphologically similar to the sulfur- and methane-oxidizing symbionts (Salerno et al., 2005). These bacterial morphotypes were also found in the mantle epithelia of post-larval and juvenile $B$. azoricus and B. heckerae (0.12-8.4 mm). Similarly, in B. childressi juveniles (4-8 $\mathrm{mm}$ ) TEM revealed bacteria that looked like the methane-oxidizing symbionts in gills as well as mantle and foot epithelia, and labeling experiments showed that these bacteria fixed carbon from methane (Streams et al., 1997). These studies suggest that Bathymodiolus is colonized by its symbionts at a very early stage and that other organs besides the gills also contain symbionts.

In this study, we focused on the following questions: (1) Do the symbionts indiscriminately infect all host tissues of juvenile Bathymodiolus? (2) Are the symbionts the only bacteria that colonize juvenile mussels? (3) Given that adult mussels are assumed to only have symbionts in their gills, is there a developmental stage at which the broad 
colonization of host tissues ends? To answer these questions, we analyzed eight $B$. puteoserpentis and five $B$. azoricus juveniles (4-21 mm) from two vent sites on the Mid-Atlantic Ridge (Supplementary Table S1) by fluorescence in situ hybridization (FISH). Semi-thin sections of whole juveniles were examined with symbiont-specific probes as well as a general eubacterial and a negative probe (see Supplement for more details about methods).

\section{Results}

Symbionts broadly colonize tissues of smallest juvenile mussels

We observed symbiont-specific FISH signals indicating the presence of both the sulfur- and the methane-oxidizing symbionts in gill bacteriocytes of all 13 Bathymodiolus juveniles (Figure 1). In the smallest individuals $(4-7 \mathrm{~mm})$, we also found
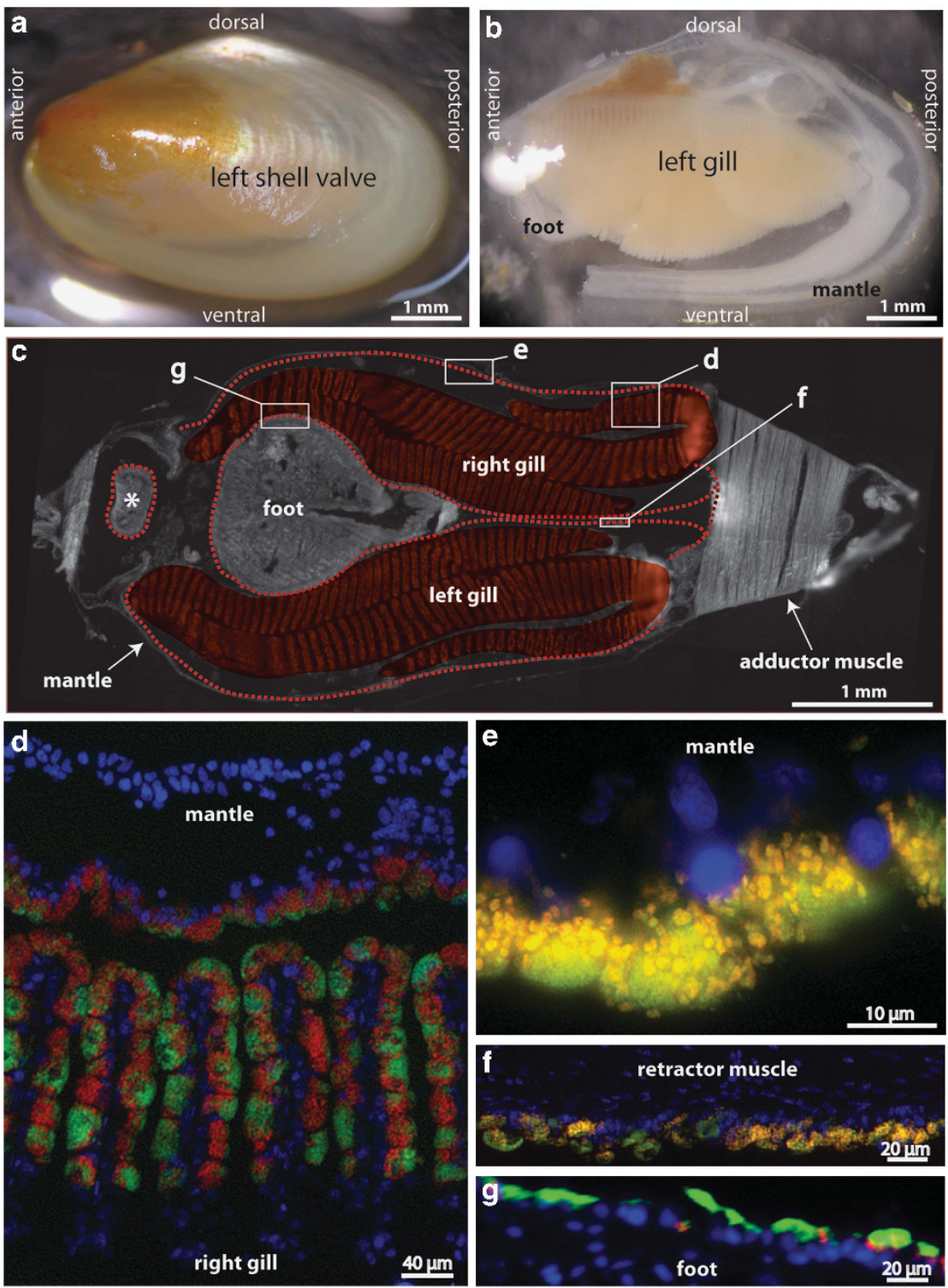

Figure 1 Symbionts colonize many different epithelial tissues in juvenile B. puteoserpentis and B. azoricus. The mussels are shown in the same orientation in all images with the anterior end on the left and the posterior end on the right. (a), (b) and (g) are B. azoricus; (c-f) are B. puteoserpentis. $(\mathbf{a}, \mathbf{b})$ Lateral view of small juvenile with (a) and without (b) shell valves. (c) Epifluorescence micrograph of a cross section (ventral view) through entire juvenile mussel. The asterisk marks the foot tip that was curled dorsally. Mussel tissue that is colonized throughout the mussel life cycle is colored in light red, whereas mussel tissues that are only infected in juveniles $<9 \mathrm{~mm}$ are marked with a red dashed line. (d-g) Symbiont-specific FISH signals of the sulfur-oxidizing symbionts (green) and the methaneoxidizing symbionts (red) in epithelial cells of (d) gills and mantle, (e) mantle, (f) retractor muscle and (g) foot. In (e) and (f) signal overlap in a triple hybridization with the two symbiont-specific probes (red and green) and the eubacterial probe (EUB338 in yellow) makes the methane-oxidizing symbionts appear orange and the sulfur-oxidizing symbionts yellow-green. Owing to differences in signal intensity of the specific probes versus the eubacterial probe, some symbionts appear more yellow than others. The triple hybridization indicates that only the symbionts and no other bacteria are present. Nuclei of the host cells are stained with DAPI (blue). 
Table 1 Relationship between shell length and symbiont colonization patterns in Bathymodiolus mussels

\begin{tabular}{|c|c|c|c|c|c|c|c|c|c|}
\hline \multirow{3}{*}{$\begin{array}{l}\text { Number of specimens } \\
\text { Shell length (mm) }\end{array}$} & \multicolumn{2}{|c|}{$\begin{array}{l}\text { B. puteo serpentis } \\
\text { (this study) }\end{array}$} & \multicolumn{2}{|l|}{$\begin{array}{l}\text { B. azoricus } \\
\text { (this study) }\end{array}$} & \multirow{3}{*}{$\begin{array}{c}\text { B. childressi } \\
\text { (Streams et al., 1997) } \\
24 \text { (in total) } \\
4-8\end{array}$} & \multicolumn{2}{|c|}{$\begin{array}{c}\text { B. heckerae } \\
\text { (Salerno et al., 2005) }\end{array}$} & \multicolumn{2}{|c|}{$\begin{array}{c}\text { B. azoricus } \\
\text { (Salerno et al., 2005) }\end{array}$} \\
\hline & 2 & 6 & 3 & 2 & & 18 & 4 & 15 & 4 \\
\hline & $6-7$ & $9-21$ & $4-5$ & $27-29$ & & $0.12-8.4$ & $\begin{array}{c}\text { adult } \\
\text { (size nd) }\end{array}$ & $0.12-8.4$ & $\begin{array}{c}\text { adult } \\
\text { (size nd) }\end{array}$ \\
\hline Symbionts in gills & Yes & Yes & Yes & Yes & Yes & Yes & Yes & Yes & Yes \\
\hline $\begin{array}{l}\text { Symbionts in epithelia } \\
\text { besides gills }\end{array}$ & $\begin{array}{l}\text { Mantle, foot and } \\
\text { retractor muscles }\end{array}$ & No & $\begin{array}{l}\text { Mantle, foot and } \\
\text { retractor muscles }\end{array}$ & No & $\begin{array}{l}\text { Mantle } \\
\text { and foot }\end{array}$ & Mantle & $\mathrm{Nd}$ & Mantle & $\mathrm{Nd}$ \\
\hline
\end{tabular}

nd, not determined.

symbiont-specific FISH signals in the epithelial cells of the mantle, foot and retractor muscles (Table 1, Figure 1), but not in other tissues or organs. The distribution and abundance of both symbionts was comparable in all organs except for the much denser colonized gills, based on microscopic observations.

The symbionts are the only bacteria that colonize juvenile host tissues

Extensive FISH analyses of all 13 juveniles showed overlap between the symbiont-specific and general eubacterial probes (as well as with DAPI staining) in all colonized host tissues (Figure 1). This indicates that the sulfur- and methane-oxidizing symbionts are the only bacteria that colonize juvenile mussels.

Larger Bathymodiolus mussels only have symbionts in their gill tissues

In contrast to $B$. azoricus and $B$. puteoserpentis juveniles $\leqslant 7 \mathrm{~mm}$, larger juveniles of both species (9-29 mm) had symbiont-specific FISH signals only in their gills (Supplementary Figure S1). To examine if this spatial restriction of colonization to the gills is also maintained in adult Bathymodiolus, we examined mantle tissues attached to gills dissected from $B$. azoricus $(n=6, \quad 55-100 \mathrm{~mm})$. We only observed the symbionts in the gills but never in the mantle.

\section{Discussion and Conclusions}

Our study provides the first FISH-based evidence that the symbionts of early-stage $B$. azoricus and $B$. puteoserpentis $\leqslant 7 \mathrm{~mm}$ colonize a wide range of epithelial tissues. Together with earlier studies on juvenile $B$. azoricus, $B$. heckerae and $B$. childressi (Streams et al., 1997; Salerno et al., 2005), these results indicate a consistent pattern of indiscriminate symbiont colonization of a wide range of epithelial tissues in Bathymodiolus $\leqslant 8.4 \mathrm{~mm}$ (Table 1). This is remarkable given that in most symbioses examined to date, infection sites are spatially limited to specific tissues or areas, even in early life stages of the host (Bright and Bulgheresi, 2010). The ontogeny of symbiont colonization has been thoroughly examined in only a few of the many bacteria-eukarya symbioses, and it is possible that wide-spread colonization of many different tissues in early life stages is not restricted to Bathymodiolus but may also occur in other hosts. Despite the pervasive infection of Bathymodiolus juvenile epithelia, our study shows that colonization is only achieved by the symbionts (although we did not check for the intranuclear bacterial parasite that can also infect these hosts (Zielinski et al., 2009). Clearly, the infection process must be highly regulated and specific to ensure that only the symbionts colonize host cells.

The most obvious explanation for the widespread colonization of host epithelia in juvenile Bathymodiolus is that it provides the host with additional nutrition. In bivalves, the gills typically develop after the mantle and foot (Raven, 1958; Streams et al., 1997), and symbionts in mantle and foot epithelia could thus provide the host with nutrients before the appearance of its gills. However, filter-feeding is assumed to be common in Bathymodiolus (Pile and Young, 1999; Riou et al., 2010) and could provide juveniles with enough food to make the nutritional contribution from the small numbers of symbionts in mantle and foot epithelia irrelevant.

In both Bathymodiolus species investigated in this study from two vent sites separated by almost $3000 \mathrm{~km}$, we observed that juveniles $\geqslant 9 \mathrm{~mm}$ only had symbionts in their gills. This indicates an ontogenetic shift in symbiont colonization from indiscriminate infection of different epithelia to a highly restricted spatial limitation to gill bacteriocytes at a developmental stage between $8.4-9 \mathrm{~mm}$. To our knowledge, such an ontogenetic shift in symbiont distribution patterns has not been previously described in Bathymodiolus or any other symbioses. Bathymodiolus gills with their greatly enlarged surface areas and cilial ventilation are by far the most efficient tissues for providing the symbionts with the oxygen and reduced compounds they need to gain energy. However, the thin outer layer of non-gill epithelia apparently has sufficient access to oxidants and reductants to harbor symbionts in juveniles $<9 \mathrm{~mm}$, and it is not clear how this would change when mussels become larger. On the other hand, the transfer and distribution of nutrients from the symbionts to the host in foot and mantle epithelia might be hindered because the 
symbiont-containing cells in these tissues are not immediately adjacent to the hemolymph lacuna as are the gill bacteriocytes. The cost of harboring symbionts in non-gill tissues might therefore outweigh their nutritional benefit. Alternatively, the immune system of early stage Bathymodiolus might not be sufficiently developed to prevent indiscriminate infection (Luna-Gonzalez et al., 2004; Huan et al., 2012). Teasing apart the roles that nutrition and the host immune system have in this ontogenetic shift will provide a better understanding of how bacterial colonization patterns are established, maintained and regulated in animal symbioses.

\section{Acknowledgements}

We thank Silke Wetzel and Agnes Zimmer for excellent technical assistance, and the chief scientists, captains and crew of the Hydromar I M60/3 and MenezMAR M82/3 cruises as well as the ROV MARUM-Quest team for their support. The funding for this study was provided by the Max Planck Society, the DFG Cluster of Excellence 'The Ocean in the Earth System' at MARUM, Bremen, and the DFG Program SPP 1144 'From Mantle to the Ocean: Energy- Material- and Life-Cycles at Spreading Axes'. CW was supported by a scholarship of the 'Studienstiftung des deutschen Volkes' and JYH by a Fulbright Fellowship.

\section{References}

Bright M, Bulgheresi S. (2010). A complex journey: transmission of microbial symbionts. Nat Rev Microbiol 8: 218-230.

Cary SC, Giovannoni SJ. (1993). Transovarial inheritance of endosymbiotic bacteria in clams inhabiting deep-sea hydrothermal vents and cold seeps. Proc Natl Acad Sci USA 90: 5695-5699.

Distel D, Felbeck H, Cavanaugh C. (1994). Evidence for phylogenetic congruence among sulfur-oxidizing chemoautotrophic bacterial endosymbionts and their bivalve hosts. J Mol Evol 38: 533-542.

Dubilier N, Bergin C, Lott C. (2008). Symbiotic diversity in marine animals: the art of harnessing chemosynthesis. Nat Rev Microbiol 6: 725-740.

Duperron S, Sibuet M, MacGregor BJ, Kuypers MMM, Fisher CR, Dubilier N. (2007). Diversity, relative abundance and metabolic potential of bacterial endosymbionts in three Bathymodiolus mussel species from cold seeps in the Gulf of Mexico. Environ Microbiol 9: 1423-1438.
Duperron S. (2010). The diversity of deep-sea mussels and their bacterial symbioses. In: Kiel S (eds) Vent and Seep Biota: Aspects from Microbes to Ecosystems. Springer: Netherlands, pp 137-167.

Endow K, Ohta S. (1990). Occurence of bacteria in the primary oocytes of vesicomyid clam Calyptogena soyae. Mar Ecol Prog Ser 64: 309-311.

Huan P, Wang HX, Liu BZ. (2012). Transcriptomic analysis of the clam Meretrix meretrix on different larval stages. Mar Biotechnol 14: 69-78.

Luna-Gonzalez A, Maeda-Martinez AN, Ascencio-Valle F, Robles-Mungaray M. (2004). Ontogenetic variations of hydrolytic enzymes in the Pacific oyster Crassostrea gigas. Fish Shellfish Immunol 16: 287-294.

Pile AJ, Young CM. (1999). Plankton availability and retention efficiencies of cold-seep symbiotic mussels. Limnol Oceanogr 44: 1833-1839.

Raven CP. (1958). Morphogenesis: the analysis of molluscan development. In: Harris JE, Yemm EW (eds) International Series of Monographs on Pure and Applied Biology. Pergamon Press: New York.

Riou V, Colaco A, Bouillon S, Khripounoff A, Dando P, Mangion P et al. (2010). Mixotrophy in the deep sea: a dual endosymbiotic hydrothermal mytilid assimilates dissolved and particulate organic matter. Mar ECol Progr Ser 405: 187-201.

Salerno JL, Macko SA, Hallam SJ, Bright M, Won YJ, McKiness Z et al. (2005). Characterization of symbiont populations in life-history stages of mussels from chemosynthetic environments. Biol Bull 208: 145-155.

Streams ME, Fisher CR, FialaMedioni A. (1997). Methanotrophic symbiont location and fate of carbon incorporated from methane in a hydrocarbon seep mussel. Mar Biol 129: 465-476.

Taylor JD, Glover EA. (2010). Chemosymbiotic Bivalves. Vent and Seep Biota: Aspects from Microbes to Ecosystems pp 107-135.

Won YJ, Hallam SJ, O’Mullan GD, Pan IL, Buck KR, Vrijenhoek RC. (2003). Environmental acquisition of thiotrophic endosymbionts by deep-sea mussels of the genus Bathymodiolus. Appl Environ Microbiol 69: 6785-6792.

Zielinski FU, Pernthaler A, Duperron S, Raggi L, Giere O, Borowski C et al. (2009). Widespread occurrence of an intranuclear bacterial parasite in vent and seep bathymodiolin mussels. Environ Microbiol 11: 1150-1167.

This work is licensed under the Creative Commons Attribution-NonCommercial-No Derivative Works 3.0 Unported License. To view a copy of this license, visit http://creativecommons.org/ licenses/by-nc-nd/3.0/

Supplementary Information accompanies the paper on The ISME Journal website (http://www.nature.com/ismej) 